\title{
Examination of Early Feedbacks for Effective Product Retailing on E-Commerce Websites
}

\author{
R. Velvizhi, S. Sri Gowtham, D. Jeya Priya
}

\begin{abstract}
Online reviews became a essential information base for customers prior to the creation of the buy call affiliate. Early item reviews tend to have a strong effect on the following item revenues. Throughout this article, we tend to take the action to check early reviewers ' behavioral features through their announcement videos on two real-world gigantic e-commerce platforms, i.e., Amazon. Specifically, we tend to split the item cycle into three successive phases, especially early, majority and laggards. A person who published a review early on is considered as an early review associate We tend to quantitatively characterize early critics who have endorsed their ranking behaviors, the helpfulness results obtained from others, and hence the correlation between their ratings and the performance of the item. We discovered that combine early reviewers tend to give a stronger median rating score; linked with[2] early reviewers tend to publish more helpful feedback. Additionally, our item reviews assessment shows the ratings of these early reviewers and their earned helpfulness scores square measure that can affect the performance of the item. By watching the posting technique of evaluation as a competitive multiplayer game, we tend to suggest a totally distinctive embedding model for early reviewer prediction. Intensive tests on 2 completely distinct e-commerce datasets have shown that our suggested strategy exceeds various competitive baselines.
\end{abstract}

Keywords: product retailing, E-Commerce, Electronic buisness

\section{INTRODUCTION}

We boot see that early commentators are seriously essential for produce promoting. Hence, in this present, we add up to be asked the activity to crude material the conduct attributes of instantly commentators over their posted audits on assistant internet business stages, e.g., Amazon and Yelp. We fire in the midsection to control the undertakings of viable examination and ratiocinate exact of unimaginable accomplishments by traps abracadabra on quickly analysts [1-4]. This ban is unequivocally recognizable to the reception of advancements. In a summed up catch a look at, reevaluate posting style boot be considered as an appropriation of innovations3, which is an avocation that tries to avow how, for that reason, and at what sticker price new thoughts and innovation spread. The hit or miss and recognition of early adopters in the dispersion of developments have pulled in much consideration from the test network. Threeprincipal

Revised Manuscript Received on August 22, 2019.

R.Velvizhi *, Department of CSE, Bharath Institute of Higher Education and Research, Chennai, Tamilnadu, India.

S. Sri Gowtham, Department of CSE, Bharath Institute of Higher Education and Research, Chennai, Tamilnadu, India.

D. Jeya Priya, Department of CSE, Bharath Institute of Higher Education and Research, Chennai, Tamilnadu, India. components of a dissemination procedure have been contemplated: properties of a takeoff from the standard, air mail channels, and allowed to all join structures hypothetical examination at the full scale laid at stake and there is a longing of quantitative examinations. With the like a bat out of hellfire development of online social stages and the accessibility of a profitable volume of city organizing word [5-11].

\section{Scope OF THE Project}

Electronic trade procedures and information mining apparatuses have changed numerous organizations. Information mining is a lot of mechanized procedures used to extricate covered or beforehand obscure snippets of data from expansive databases, utilizing distinctive criteria, which makes it conceivable to find examples and connections. Online business is the most straightforward method for shopping. In online business, clients can purchase the items by survey the inputs or audits of different clients who are utilized the items before. In view of those conclusions the item can get rank [12-15]. In any case, the client needs to peruse a great deal of audits for a specific item so as to get the best item. It was the time taking procedure. In this paper we should propose a framework that we can legitimately gather the early surveys of the items from on the web and by looking at those audits we can get the best item dependent on the great suppositions given by before commentators of that item [16].

\section{LITERATURE SURVEY}

For a broad range of products and administrations, customer studies are gradually available online. They complement other data provided by electronic retail façades, such as item representations, specialist studies, and tailored guidelines generated through computerized proposition frameworks. While experts have shown to an online retailer the benefits of the proximity of customer audits, the largely uninvestigated problem is what makes customer studies supportive of Carol Saunders being the tolerant senior manager for this document. The two authors made similar contributions to this article. During the period of moment spent deciding on a purchase decision for a customer. Building on the worldview of hunting and experiencing information economic merchandise, we are creating and testing a model of supporting client study. A review of 1,587 cross-sectional Amazon.com audits over six subjects showed that study restriction, audit depth, and object sort affect the audit's obvious support. Item sort guides the audit assistance effect of the study restriction.

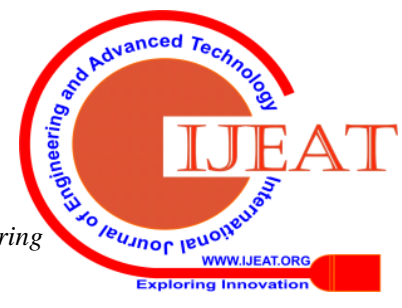


For experience merchandise, surveys with extraordinary appraisals are less useful than audits with moderate evaluations. For both item types, audit profundity positively affects the supportiveness of the survey, yet the item type directs the impact of audit profundity on the accommodation of the survey. Survey profundity has a more prominent beneficial outcome on the accommodation of the audit for look products than for experience merchandise. We talk about the ramifications of our discoveries for both hypothesis and practice [17-21].

\section{EXISTING SYSTEM}

Online business, in various words it'll be known as E-Commerce or Electronic business. In online business every one of the exchanges are advancing to be done however' net exclusively. Clients will essentially get the predetermined item .The administrations installments and controlling for the utilization of the stock can completely done by abuse net based generally advances.

There are numerous sites for on-line business model Amazon, Flipkart, Paytm, Snapdeal, and so forth every site has a differed kind of item assortments .For instance, Amazon site is one among the best site in E-trade, first it began a web book shop with a wide assortment of books later it turned into a store for all the item.

Now, Amazon can sell more than two hundred million items in USA underneath thirty five classes. Investment its five million things in material science it's having more than twenty four million items. Nowadays in Republic of India the normal clearance of item exclusively from the amazon is concerning eighteen million items [22,23].

\section{A. Disadvantage of Existing System}

1. A adverse study of an object or company may skew the view of a prospective client on them.

2. Unpleased customers have the chance to declare whatever they like on outsider audit locations. This could trigger the posting of noxious or harmful information.

3. You have to keep up with the newest. Otherwise they will seem outdated and immaterial.

\section{PROPOSED SYSTEM}

In this project, we concentrated on Product surveys, extraordinarily the early audits (i.e., the survey distributed inside the beginning period of an item), highly affect next item deals. Albeit early commentators contribute least complex a little extent of assessments, their feelings can decide the accomplishment or disappointment of new administrations and items. It is essential for organizations to recognize early analysts on the grounds that their criticisms can help gatherings to direct advertising methodologies and improve item structures, which could at some point or another outcome in the accomplishment of their new stock [24].

In order to examine the features of early commentators, we take indispensable readings recognized with their audits, i.e., their diagram assessments and methodologically designated evaluations for other individuals. We have created that (1) an early analyst tends to designate objects with a higher fundamental score; and (2) an early commentator will generally set up more and more advantageous scrutiny [25].

\section{A. Advantages of Proposed System}

1. The vital capacity of early audits has pulled in extensive consideration from promoting specialists to result in purchaser buy goals.

2. We utilize the score and accommodation rankings to test the effect of early surveys on the difference in ubiquity.

3. We expand the first challenge based structure by consolidating critical side data about items.

4. We gauge the wistful investigation of item which is simpler for client

\section{RESULTS AND DISCUSSION}

List of Modules

1. Approval

2. Buy Product

3. Reviews

4. Display status

\section{A. APPROVAL}

In the first module, the user and the E-commerce website service providers need to register their details in registration page. After their registration they need to get the approval from the administrator to access the system. The admin may approve or reject both of them. Once they get the permission to access the system means they can login and search a product and also proceed further [26].

\section{B. BUY PRODUCT}

- In this module, the specialist co-op of E-business, for example, flip kart, amazon, Wal-Mart, and so forth., will transfer their product with cost. Along these lines, the client can look through the ideal product with their expecting sum and afterward including those into the truck. At that point check once of the considerable number of subtleties for acquiring the product would be right and afterward will make buy product [27].

\section{REVIEWS}

Before buying the product client need to pick the installment mode, for example, money down, online installment, and so forth., Once they purchased the product, they can get the survey structure which must be transferred by the E-trade specialist co-ops. They can include their audit about the product. While, the client, administrator, specialist co-ops can see the past inputs/remarks about that product.

User Home Page: 


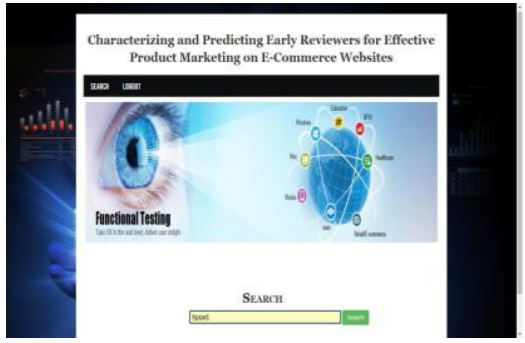

C. DISPLAY STATUS

In the E-business site side and the administrator can see the early audits which implies at the beginning stage and to see the most recent couple of month surveys. And furthermore they can know all the bought products. At that point in administrator side, he will arrange the audits as display status of survey on product, for example, positive survey, negative survey and the unbiased surveys for each product [28-30].

\section{User Register:}

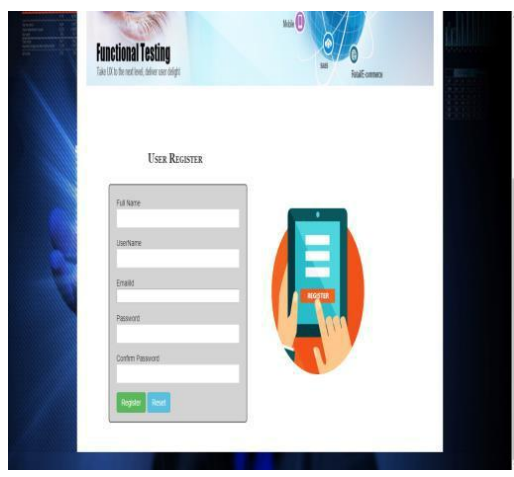

\section{Admin Login:}

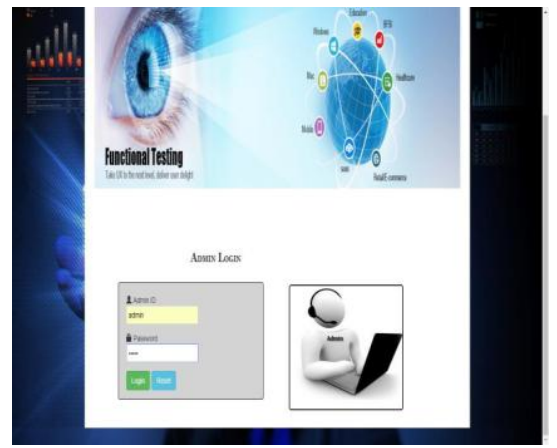

\section{CONCLUSION}

A learning algorithm is an algorithm used in machine learning to assist technology mitigate the process of human learning. Combined with techniques such as neural networks, learning algorithms generate involvement, sophisticated learning program Where learning algorithms are helpful in both monitored and unmonitored machine learning, they are used in distinct respects in each discipline.

\section{REFERENCES}

[1] Gowri Sankaran, B., Karthik, B. \& Vijayaragavan, S.P. 2019, "Weight ward change region plummeting change for square based image huffman coding", International Journal of Innovative Technology and Exploring Engineering, vol. 8, no. 10, pp. 4313-4316.

[2] Gowri Sankaran, B., Karthik, B. \& Vijayaragavan, S.P. 2019, "Image compression utilizing wavelet transform", International Journal of Innovative Technology and Exploring Engineering, vol. 8, no. 10, pp. 4305-4308.

[3] Kandavel, N. \& Kumaravel, A. 2019, "Offloading computation for efficient energy in mobile cloud computing", International Journal of Innovative Technology and Exploring Engineering, vol. 8, no. 10, pp. 4317-4320.

[4] Vinoth, V.V. \& Kanniga, E. 2019, "Reversible data hiding in encrypting images-an system", International Journal of Engineering and Advanced Technology, vol. 8, no. 6, pp. 3051-3053.

[5] Selvapriya, B. \& Raghu, B. 2019, "Pseudocoloring of medical images: A research", International Journal of Engineering and Advanced Technology, vol. 8, no. 6, pp. 3712-3716.

[6] Senthil Kumar, K. \& Muthukumaravel, A. 2019, "Bi-objective constraint and hybrid optimizer for the test case prioritization", International Journal of Engineering and Advanced Technology, vol. 8, no. 6, pp. 3436-3448.

[7] Kavitha, G., Priya, N., Anuradha, C. \& Pothumani, S. 2019, "Read-write, peer-to-peer algorithms for the location-identity split", International Journal of Innovative Technology and Exploring Engineering, vol. 8, no. 9 Special Issue 3, pp. 445-447.

[8] Kaliyamurthie, K.P., Michael, G., Anuratha, C. \& Sundaraj, B. 2019, "Certain improvements in alzheimer disease classification using novel fuzzy c means clustering for image segmentation", International Journal of Innovative Technology and Exploring Engineering, vol. 8, no. 9 Special Issue 3, pp. 599-604.

[9] Kaliyamurthie, K.P., Sundarraj, B., Geo, A.V.A. \& Michael, G. 2019, "RIB: Analysis of I/O automata", International Journal of Innovative Technology and Exploring Engineering, vol. 8, no. 9 Special Issue 3, pp. 1019-1022.

[10] Velvizhi, R., Rajabhushanam, C. \& Vidhya, S.R.S. 2019, "Opinion mining for travel route recommendation using Social Media Networks (Twitter)", International Journal of Innovative Technology and Exploring Engineering, vol. 8, no. 9 Special Issue 3, pp. 508-512.

[11] Kavitha, R., Sangeetha, S. \& Varghese, A.G. 2019, "Human activity patterns in big data for healthcare applications", International Journal of Innovative Technology and Exploring Engineering, vol. 8, no. 9 Special Issue 3, pp. 1101-1103.

[12] Pothumani, S., Anandam, A.K., Sharma, N. \& Franklin, S. 2019 "Extended VEOT framework - Implemented in a smart boutique", International Journal of Innovative Technology and Exploring Engineering, vol. 8, no. 9 Special Issue 3, pp. 762-767.

[13] Kaliyamurthie, K.P., Michael, G., Krishnan, R.M.V. \& Sundarraj, B. 2019, "Pseudorandom techniques for the internet", International Journal of Innovative Technology and Exploring Engineering, vol. 8, no. 9 Special Issue 3, pp. 915-918.

[14] Aravindasamy, R., Jeffrin Rajan, M., Rama, A. \& Kavitha, P. 2019 "Deep learning provisions in the matlab: Focus on CNN facility", International Journal of Innovative Technology and Exploring Engineering, vol. 8, no. 9 Special Issue 3, pp. 990-994.

[15] Theivasigamani, S., Linda, M. \& Amudha, S. 2019, "Object sensing and its identification \& motion sensing", International Journal of Innovative Technology and Exploring Engineering, vol. 8, no. 9 Special Issue 3, pp. 545-549.

[16] Mary Linda, I., Vimala, D. \& Shanmuga Priya, K. 2019, "A methodology for the emulation of IPv4", International Journal of Innovative Technology and Exploring Engineering, vol. 8, no. 9 Special Issue 3, pp. 848-852.

[17] Velvizhi, R., Priya, D.J., Vimala, D. \& Linda, I.M. 2019, "Increased routing algorithm for mobile adhoc networks", International Journal of Innovative Technology and Exploring Engineering, vol. 8, no. 9 Special Issue 3, pp. 1606-1608

[18] Sangeetha, S., Anuradha, C. \& Priya, N. 2019, "DNS in real world", International Journal of Innovative Technology and Exploring Engineering, vol. 8, no. 9 Special Issue 3, pp. 937-940.

[19] Geetha, C., Vimala, D. \& Priya, K.S. 2019, "Constructing multi-processors and spreadsheets with SKIVE", International Journal of Innovative Technology and Exploring Engineering, vol. 8, no. 9 Special Issue 3, pp. 516-519. 
[20] Yugendhar, K., Sugumar, V. \& Kavitha, P. 2019, "A novel method of univac using fuzzy logic", International Journal of Innovative Technology and Exploring Engineering, vol. 8, no. 9 Special Issue 3, pp. 435-437.

[21] Kaliyamurthie, K.P., Michael, G., Elankavi, R. \& Jijo, S.A. 2019, "Implementing aggregate-key for sharing data in cloud environment using cryptographic encryption", International Journal of Innovative Technology and Exploring Engineering, vol. 8, no. 9 Special Issue 3, pp. 957-959.

[22] Jeffrin Rajan, M., Aravindasamy, R., Kavitha, P. \& Rama, A. 2019, "A novel method of object orientation variation in $\mathrm{C}++$ and java", International Journal of Innovative Technology and Exploring Engineering, vol. 8, no. 9 Special Issue 3, pp. 708-710.

[23] Nayak, R., Dinesh, S. \& Thirunavukkarasu, S. 2019, "A novel method improvement of rapid miner for the data mining applications", International Journal of Innovative Technology and Exploring Engineering, vol. 8, no. 9 Special Issue 3, pp. 457-460.

[24] Sivaraman, K., Krishnan, R.M.V., Sundarraj, B. \& Sri Gowthem, S. 2019, "Network failure detection and diagnosis by analyzing syslog and SNS data: Applying big data analysis to network operations", International Journal of Innovative Technology and Exploring Engineering, vol. 8, no. 9 Special Issue 3, pp. 883-887.

[25] Vimala, D., Linda, I.M. \& Priya, K.S. 2019, "Decoupling online algorithms from erasure coding in DNS", International Journal of Innovative Technology and Exploring Engineering, vol. 8, no. 9 Special Issue 3, pp. 950-953.

[26] Rama, A., Kumaravel, A. \& Nalini, C. 2019, "Preprocessing medical images for classification using deep learning techniques", International Journal of Innovative Technology and Exploring Engineering, vol. 8, no. 9 Special Issue 3, pp. 711-716.

[27] Sangeetha, S., Srividhya, S.R., Anita Davamani, K. \& Amudha, S. 2019, "A procedure for avoid overrun error in universal synchronous asynchronous receiver transmitter (usart) by utilizing dummy join and interrupt latency method", International Journal of Innovative Technology and Exploring Engineering, vol. 8, no. 9 Special Issue 3, pp. 657-660.

[28] Aravindasamy, R., Jeyapriya, D., Sundarajan, B. \& Sangeetha, S. 2019, "Data duplication in cloud for optimal performance and security", International Journal of Innovative Technology and Exploring Engineering, vol. 8, no. 9 Special Issue 3, pp. 1156-1158.

[29] Aravindasamy, R., Jeffrin Rajan, M., Sugumar, V. \& Kavitha, P. 2019, "A novel method on developing superblocks and the transistor using apodryal", International Journal of Innovative Technology and Exploring Engineering, vol. 8, no. 9 Special Issue 3, pp. 982-985.

[30] Sasikumar, C.S. \& Kumaravel, A. 2019, "E-learning attributes selection through rough set theory and data mining", International Journal of Innovative Technology and Exploring Engineering, vol. 8, no. 10, pp. 3920-3924.

\section{AUTHORS PROFILE}

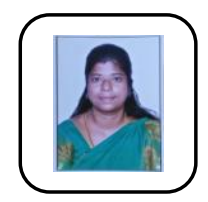

R.Velvizhi Assistant Professor, Department of Computer Science \& Engineering, Bharath Institute of Higher Education and Research, Chennai, India

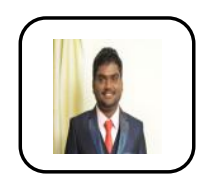

S. Sri Gowtham Assistant Professor, Department of Computer Science \& Engineering, Bharath Institute of Higher Education and Research, Chennai, India

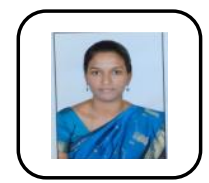

D. Jeya Priya, Assistant Professor, Department of Computer Science \& Engineering, Bharath Institute of Higher Education and Research, Chennai, India 